\title{
The Development of Foreign Capital Insurance Market, FDI and Economic Growth in China
}

\author{
Dongsheng Wang*, Yumei Li \\ College of Economics and Management, Southwest University, Chongqing, China \\ Email: *dswang@swu.edu.cn
}

How to cite this paper: Wang, D.S. and Li, Y.M. (2019) The Development of Foreign Capital Insurance Market, FDI and Economic Growth in China. Modern Econo$m y, 10,872-885$.

https://doi.org/10.4236/me.2019.103058

Received: February 18, 2019

Accepted: March 19, 2019

Published: March 22, 2019

Copyright ( 2019 by author(s) and Scientific Research Publishing Inc. This work is licensed under the Creative Commons Attribution International License (CC BY 4.0).

http://creativecommons.org/licenses/by/4.0/

(c) (i) Open Access

\begin{abstract}
This paper analyzes the relationship among foreign capital insurance market, FDI and economic growth in China. We use unit root test, least square regression and Granger causality test to examine the relationship with the data over the period 1984-2015. It is found that the development of China's foreign capital insurance market has not promoted China's economic growth, FDI has promoted China's economic growth, and China's economic growth has generally promoted the development of foreign capital insurance market. The channels of insurance market acting on economic growth are not smooth enough for foreign capital in China, and its action modes may be mainly applicable to China's domestic insurance market.
\end{abstract}

\section{Keywords}

China's Development of Foreign Capital Insurance Market, FDI, Economic Growth, Relationship

\section{Introduction}

After 40 years of rapid development since the reform and opening up in 1978, China has maintained double-digit economic growth. It has become the world's second-largest economy, with a gross domestic product of 74.4 trillion RMB yuan, or 10.7 trillion US dollars in 2016. The Shenzhen branch of Hong Kong Minan Insurance Co., Ltd. was established in 1982, and for the first time since the reform and opening up, China allowed foreign capital insurance institutions ${ }^{1}$ to enter China to carry out business. In 1992, AIA (American International Assurance Co. Ltd) set up a branch at Shanghai in China to develop foreign capital life insurance business, later foreign capital insurance institutions have taken a ${ }^{1}$ Insurance institutions invested by Hong Kong, Macao, and Taiwan in mainland China are also regarded as foreign capital insurance institutions. 
keen interest in China's huge insurance market potential, continuously entering mainland China, setting up branches or establishing joint ventures and so on. The number of foreign capital insurance institutions continues to increase, the premium income increases rapidly, the scale of assets continues to increase, and the foreign capital insurance market continues to grow and expand. In 2015, the total number of foreign-funded insurance institutions reached 55, and in 2016, insurance premiums for foreign capital insurance institutions reached 157.741 billion RMB yuan, or $\$ 22.72$ billion US dollars, and total assets reached 911.807 billion RMB yuan, or $\$ 131.329$ billion US dollars. China implements the policy of reform and opening to the outside world, actively attracts foreign capital, and provides a large number of favorable conditions for foreign capital to enter China. China's foreign direct investment (FDI) is on the whole on the rise, providing a large amount of funds for China's production and construction and financial services. By 2016, the scale of FDI had reached 126 billion US dollars.

China's foreign capital insurance market refers to the market where foreign insurance institutions in China conduct insurance exchanges. The development of China's foreign capital insurance market refers to the changes in the structure of China's foreign capital insurance market, such as the changes of size of institutional assets and the volume of transactions. What are the relationships among the development of China's foreign capital insurance market, FDI and China's economic growth? Does the development of foreign capital insurance market promote China's economic growth? Is the development of China's foreign capital insurance market promoting China's economic growth or China's economic growth promoting the development of China's foreign capital insurance market? These are of great reference value for the Chinese government to carry out macro-control and formulate insurance market policies.

With the unique sight, this paper discusses the relationship between financial market and economic growth from the angle of the foreign capital insurance market and FDI. This will do great help for a country to get acquaintance of its foreign capital insurance market's function, FDI's influence and the government's work situation. This research will strongly support the decisions and policies on the foreign capital insurance market and FDI, and give its own feasible suggestions. Based on the theoretical and empirical analysis, we can come into conclusions: Through the transaction of the insurance market, to promote the production and sale of enterprises, to share individual risks, to transfer and manage risks, to pay compensation to insurers, to obtain mutual financing from other insurers, and to strengthen the production of information, to reduce social disputes and to cultivate credit environment have promoted the economic growth; FDI can promote economic growth by directly investing an economy and providing capital to foreign insurance institutions. But in China, these pathways are not smooth. In the meanwhile, China's foreign direct investment has promoted China's economic growth, the development of foreign capital insurance market has not promoted China's economic growth, and China's eco- 
nomic growth has generally promoted the development of foreign capital insurance market.

This paper is divided into the following parts: the second part is literature review, combing the existing relevant research; the third part is theoretical analysis; the fourth part is empirical analysis, using unit root test, the least square regression analysis and granger causality test to test the relationships among variables, as well as the conclusions and explanations; the fifth part is the policy recommendations.

\section{Literature Review}

Raymond. W. Goldsmith (1969), an American economist, made an original research on the financial development and economic development in his publication "financial structure and financial development", especially emphasizing the positive and active role of financial development to economic development. The promotion of the developed financial structure to economic growth is through raising the total level of savings and investment as well as the effective allocation of funds in the two channels. In 1973, the American economists E.S. Shaw and R.I. Mackinnon published respectively "the financial deepening in the financial development" and" the monetary and capital in the economic development". Two people studied the dialectical relationship between financial development and economic growth in developing countries from different angles. In the study, they took the monetary and financial problems of developing countries as the research object, and put forward the theory of financial repression and the theory of financial deepening. After that, such researches can be divided into three categories, one is the relationship between financial activities and economic growth; the other is the relationship between the development of financial institutions and the economic growth; the third is the relationship between financial market and the economic growth.

The research on the relationship between insurance development or insurance market and economic growth is divided into four categories.

First category is the positive effect of insurance on economic growth. Liyan Han, Donghui Li et al. [1] analyzed the relationship between insurance development and economic growth by using dynamic panel GMM model on 77 countries between 1994 and 2005, and came to the conclusion that there was a positive correlation between insurance development and economic growth. PEIFEN CHEN et al. [2] analyzed the effect of life insurance on economic growth, and found that the development of life insurance had positive impact on economic growth, and its impact on middle-income countries had been eased and had been strengthened in low-income countries. Gyu, Choi Seok [3] used the cointegration and error correction model to analyze the causal relationship between the financial role of life insurance and regional economic growth in 16 regions of South Korea, and concluded that there was a causal relationship between the role of life insurance and regional economic growth in most regions, 
and the financial role of regional life insurance could affect regional economic growth. Liam C. Malloy et al. [4], using 48 nearby states and an OECD country database, established a model of expansion of life insurance to state and national economic growth for the last 20 years, and found that increasing the coverage of health insurance for wage earners, especially through similar government-funded medical projects, could be accompanied by rapid growth in gross domestic product and employment rate. Sajid Mohy Ul Din et al. [5] examined the relationship between insurance and economic growth in 20 countries during 2006 2015. Using the fixed-effect model, it was found that there was a positive and significant relationship between the measured book premiums, the density and economic growth for the life insurance in developed and developing countries, and there was a statistically significant relationship between nonlife insurance and economic growth in developing countries. Chunyang Zhou et al. [6] applied dynamic panel technology to check the relationship between insurance action and economic growth by using the return of insurance securities as an indicator of insurance activities. The results showed that when the changes of the return of market index was controlled, there was a significant and positive relationship between the return of insurance security and the future economic growth, and the effect of law and regulation on the link between the role of insurance and economic growth was more pronounced in developed markets countries than in emerging markets countries. Concha Angela et al. [7] assessed the relationship between the use of insurance and economic growth in 11 Latin American countries during the period 1980-2009. According to the growth equation, the use of insurance increased by 1 percent, and the economy would grow by 0.17 percent to 0.44 percent. Nam Sangwook [8] discussed the long term relationship between China's insurance development and economic growth, using vector error correction model and impact response function technology, and empirically obtained the positive and significant relationship between per capita premium income and per capita national income.

Second category is that there is a bidirectional promotion relationship between insurance and economic growth. Nam Sangwook [9] applied GMM model and panel VAR model to the cross-section data of 16 developed countries from 1980 to 2004 for analyzing the contribution of insurance industry to the whole economy. It was found that there was a bidirectional push between the development of insurance industry and economic growth. Shrutikeerti Kaushal et al. [10] analyzed the relationship between India's banking, insurance and economic growth in the late stage of liberalization, and found that there was a longterm relationship between banking, insurance and economic growth, there was a two-way causal relationship between insurance activity and economic growth. $\mathrm{Su}$ Chi-Wei et al. [11] examined the relationship between insurance development and economic growth using the bootstrap panel Granger causality test, finding two-way Granger causality between life insurance and macroeconomics in high-income countries. Rudra P. Pradhan et al. [12] used Granger causality 
test with the data for 19 Eurozone countries from 1980 to 2014 to test the relationship between insurance market density and economic growth, it was concluded that a one-way or two-way causal relationship existed between the two at the same time.

Another category is the one-way negative relationship from economic growth to insurance. Nam Sangwook [8] analyzed the long-term relationship between insurance development and economic growth in China by using vector error correction model, impulse response function and variance decomposition technique, and found that there was a negative interaction between interest rate, inflation and other key economic indicators with the life insurance market. D. O. Olayungbo [13] examined the asymmetric nonlinear relationship between insurance and economic growth in Nigeria from 1976 to 2010. A strong and significant relationship between long-term high-value GDP and low-level insurance was found.

The fourth category is that the relationship between insurance and economic growth on a country-by-country, region-by-region and situation-by-situation basis varies. D. O. Olayungbo et al. [14] analyzed the relationship between insurance and economic growth in eight African countries during 1970-2013 using a Bayesian time-varying parameter vector autoregressive model with random fluctuations, and found that Egypt had a positive effect, Kenya, Mauritius and South Africa had short-term negative long-term positive relationship, Algeria, Nigeria, Tunisia and Zimbabwe showed a negative effect. Damian Ward et al. [15] examined the short term and long term dynamic relationship between economic growth and insurance growth in nine OECD countries, and found that some countries' insurance industry was the Granger cause of economic growth, while others were the opposite, the relationship varied on countries and country's circumstances. Hu Hongbing et al. [16] analyzed the relationship between insurance activity and economic growth in 31 regions of China from 1997 to 2011 by using the bootstrap Granger causality test. The results showed that there were neutral characteristics in 21 regions, while economic growth was the Granger cause of insurance activities in 7 regions, while in Jiangsu, Zhejiang and Shandong provinces, insurance activity was the Granger cause of economic growth. Chen Lu et al. [17] and Sajid Mohy Ul Din et al. [18] believed that life insurance had a positive effect on economic growth when the time selection rate and productivity of human capital were sufficiently low or for India, Pakistan and England, while when income losses were large enough or for the United States, China and Malaysia, life insurance had a negative effect on economic growth. Abdul Latif Alhassan [19] and Sopan Han Byong [20] studied the relationship between insurance market and economic growth, and found respectively that apart from the two-way causal relationship for Morocco, the other seven African countries had one-way causality; the latter that in China, gross premium income had a positive effect on GDP per capita, but economic growth was the Granger cause of premium growth. The reverse relationship was not. 
There are more studies on the relationship between insurance and economic growth, but less on the relationship between the development of insurance market and economic growth, while the research on the development of foreign capital insurance market and economic growth in China is a blank.

\section{Theoretical Analysis}

Through the transactions in the insurance market, insurance institutions have the function of accumulating and using surplus social funds and channeling funds into the hands of the scarce. Insurance institutions collect premium income, and through various investment activities, directly or indirectly transfer of funds into the hands of enterprises, promoting production and sales, creating new values and promoting economic growth; the insurance market can socialize individual risks through insurance transactions, which insurance institutions share risks among individuals, thus individuals can boldly engage in economic affairs, boldly carry out scientific and technological innovations, expand foreign economic exchanges, promote production and exchange, improve production and service efficiency, raise the level of productive forces, and expand imports and exports. thus promote economic growth; insurance markets and insurance institutions, through insurance transactions, can transfer and manage risks, thereby to stimulate savings and investment, and to promote efficiency in production and services through raising the efficiency in the allocation of resources, thus promote economic growth; through transactions in the insurance market, insured persons can receive compensation for property losses and life insurance payments, thus providing a substitute for savings, allowing people to live and produce securely, ensuring the normal operation of the economy and to expand consumption at ease, and through transactions in the insurance market, high-tech enterprises can obtain such support; by participating in the activities of the insurance market, policy holders can obtain mutual risk financing from other policy holders through insurance intermediary, increasing the theoretical capital, and promote economic growth through the role of capital mechanism on economy; asymmetric information will lead to adverse selection in advance and moral hazard after the event, which objectively requires an agent specializing in information production, and insurance institutions can act as such agents, thus facilitating financing and avoiding operational risks, allocating of capital to sectors most in need, thereby promoting economic growth; participation of insurance institutions in social management, can reduce the disputes that may arise between insurance parties, maintain normal social relations between governments, enterprises and individuals, so that social and economic organizations can safely devote themselves to production and life, which is conducive to economic development and promote economic growth; in addition, the operation of insurance institutions in the insurance market depends on their own credit as the yardstick and plays an imperceptible role in cultivating social honesty, it is beneficial to the construction of honest society, to the normal and stable operation of social economy and to economic growth. 
Foreign direct investment (FDI) can directly invest in China's domestic economy, provide capital for the development of foreign capital insurance institutions in China, promote the transactions in China's foreign capital insurance market and expand or change the number, scale and assets of foreign capital insurance institutions. Through the above-mentioned insurance function and function play, it can impact the China's economic growth. With the continuous expansion of FDI and the continuous opening of China's foreign capital insurance market, more foreign capital will enter the foreign capital insurance market, and the foreign capital insurance market will continue to expand, thus promoting China's economic growth; on the other hand, with the increase of foreign direct investment, foreign businessmen directly set up enterprises or companies in China and put forward new requirements for insurance in the course of operation of enterprises or companies. and these foreign-funded enterprises and companies have a natural affinity to foreign-funded insurance institutions or markets, expanding the demand for foreign-funded insurance institutions or markets, and with the support of foreign capital, foreign capital insurance market transactions and foreign capital insurance institutions will inevitably appear and develop in a large number to improve the mechanism of insurance and promote China's economic growth. Of course, the decline in foreign direct investment, will also have the opposite effect.

\section{Empirical Analysis}

\subsection{Variables, Data Sources and Models}

The explanatory variables of this study include RFPI the real premium income of the foreign capital insurance institutions, RFDI the real foreign direct investment, RFIA the real total assets of the foreign capital insurance institutions, RFPIP the real premium income of foreign capital insurance institutions per capita, RFDIP the real foreign direct investment per capita, RFIAP the real assets of foreign capital insurance institutions per capita, $U$ the number of foreign capital insurance institutions, and the explained variables include RGDP the actual gross domestic product, RGDPP the real GDP per capita, DPR the real GDP growth rate, and DPPR the real GDP growth rate per capita, except DPR and DPPR, the others are all logarithmic. The summary statistics of the variables can be seen in Table 1.

Table 1. The summary statistics of the relative variables.

\begin{tabular}{cccccccccccc}
\hline & DPPR & DPR & lnRFDI & lnRFDIP & lnRFIA & lnRFIAP & lnRFPI & $\operatorname{lnRFPIP}$ & $\operatorname{lnRGDP}$ & $\operatorname{lnRGDPP}$ & $\ln$ \\
\hline Mean & 0.09187 & 0.10183 & 4.46450 & 1.94916 & 2.12370 & -0.39164 & 1.38343 & -1.13191 & 10.24792 & 7.73710 & 2.11226 \\
Maximum & 0.16897 & 0.17661 & 5.45915 & 2.85842 & 7.37025 & 4.74948 & 5.37875 & 2.75799 & 11.76083 & 9.14254 & 4.02535 \\
Minimum & -0.05528 & -0.04083 & 2.48515 & 0.13992 & -3.11957 & -5.46480 & -3.04269 & -5.38792 & 8.84572 & 6.50698 & 0.00000 \\
Std. Dev. & 0.04478 & 0.04395 & 0.98313 & 0.90557 & 3.73188 & 3.65292 & 3.03723 & 2.95833 & 0.92814 & 0.84848 & 1.61541 \\
Observations & 32 & 32 & 32 & 32 & 32 & 32 & 32 & 32 & 32 & 32 & 32 \\
\hline
\end{tabular}


The sample data are annual data, the time is from 1984 to 2015, Data sources are Wind database and China Insurance Yearbook 1983-2017.

According to the endogenous growth model

$$
Y=A K
$$

where $Y$ is the output, $A$ is the technical factor, $K$ is the capital.

We assume

$$
K=\mathrm{FPI}^{\alpha} \mathrm{FDI}^{\beta} \mathrm{FIA}^{\gamma}
$$

Here FPI is the premium income of foreign capital insurance institutions. FDI is foreign direct investment. FIA is the assets of foreign capital insurance institutions, $\alpha, \beta, \gamma$ are the coefficients of elasticity of the premium income of foreign capital insurance institutions, foreign direct investment, and assets of foreign capital insurance institutions to capital.

The formula (2) is brought into the formula (1).

$$
Y=A(\mathrm{FPI})^{\alpha}(\mathrm{FDI})^{\beta}(\mathrm{FIA})^{\gamma}
$$

Take the natural logarithm on both sides of formula (3).

$$
\ln (Y)=\ln (A)+\alpha \ln (\mathrm{FPI})+\beta \ln (\mathrm{FDI})+\gamma \ln (\mathrm{FIA})
$$

On both sides of formula (3) divided by the total population of China, there are

$$
\frac{Y}{N}=A N^{[(\alpha+\beta+\gamma)-1]}\left(\frac{\mathrm{FPI}}{N}\right)^{\alpha}\left(\frac{\mathrm{FDI}}{N}\right)^{\beta}\left[\frac{\mathrm{FIA}}{N}\right]^{\gamma}
$$

If the natural logarithm is taken on both sides of formula (5), there is

$$
\begin{gathered}
\ln \bar{Y}=\ln \bar{A}+\alpha \ln \overline{(F P I)}+\beta \ln \overline{(\mathrm{FDI})}+\gamma \ln \overline{(\mathrm{FIA})} \\
\bar{A}=A N^{[(\alpha+\beta+\gamma)-1]}
\end{gathered}
$$

Here is $\bar{Y}$ the per capita output, $\bar{A}$ constant, $\overline{\text { FPI }}, \overline{\text { FDI }}, \overline{\text { FIA }}$ respectively, for the premium income of foreign capital insurance institutions per capita, foreign direct investment per capita and foreign capital insurance institution assets per capita.

The software which is used in this article is EVIEWS.

\subsection{Unit Root Test}

The natural logarithm of the variable RFPI, RFDI, RFIA, RFPIP, RFDIP, RFIAP, U, RGDP, RGDPP and DPR are tested respectively in unit root test. For nonstationary sequences, we continue to judge the stationarity of the first order difference, and the test results are shown in Table 2.

From Table 2, we can see that DPR, DPPR, lnRGDP, lnRGDPP is a horizontal stationary sequence, i.e., I (0). and lnRFPI, lnRFDI, lnRFIA, lnRFPIP, lnRFDIP, lnRFIAP and $\ln U$ are first order integration, i.e., I (1), that is the first order dif-

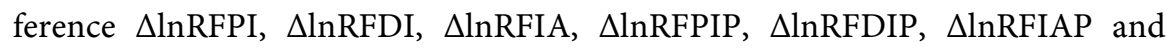
$\Delta \mathrm{luU}$ are stable sequences. 
Table 2. The unit root test on variables of the development of foreign capital insurance market and economic growth in China.

\begin{tabular}{|c|c|c|c|c|c|c|c|c|}
\hline \multirow{2}{*}{ variables } & \multicolumn{4}{|c|}{ level } & \multicolumn{4}{|c|}{ 1st difference } \\
\hline & ADF-T & $(\mathrm{C}, \mathrm{T}, \mathrm{L})$ & $\mathrm{P}$ & SC & ADF-T & $(\mathrm{C}, \mathrm{T}, \mathrm{L})$ & $\mathrm{P}$ & SC \\
\hline DPR & $-3.4597^{\star *}$ & $(\mathrm{C}, 0,1)$ & 0.0165 & -3.6907 & & & & \\
\hline DPPR & $-3.2827^{\star *}$ & $(\mathrm{C}, 0,1)$ & 0.0248 & -3.6768 & & & & \\
\hline LnRGDP & $-3.3311^{\star}$ & $(\mathrm{C}, \mathrm{T}, 1)$ & 0.0806 & -3.9526 & & & & \\
\hline $\operatorname{lnRGDPP}$ & $-3.2883^{*}$ & $(\mathrm{C}, \mathrm{T}, 1)$ & 0.0875 & -3.9285 & & & & \\
\hline $\ln R F P I$ & & & & & $-5.0757^{\star * *}$ & $(\mathrm{C}, \mathrm{T}, 0)$ & 0.0015 & 1.1277 \\
\hline $\operatorname{lnRFDI}$ & & & & & $-4.4165^{\star * *}$ & $(\mathrm{C}, \mathrm{T}, 1)$ & 0.0078 & -0.2887 \\
\hline $\ln R F I A$ & & & & & $-3.7474^{\star *}$ & $(\mathrm{C}, \mathrm{T}, 4)$ & 0.0367 & 1.5238 \\
\hline lnRFPIP & & & & & $-5.0650^{\star * *}$ & $(\mathrm{C}, \mathrm{T}, 0)$ & 0.0016 & 1.1297 \\
\hline $\operatorname{lnRFDIP}$ & & & & & $-4.4192^{\star * *}$ & $(\mathrm{C}, \mathrm{T}, 1)$ & 0.0078 & -0.2877 \\
\hline lnRFIAP & & & & & $-3.7416^{\star *}$ & $(\mathrm{C}, \mathrm{T}, 4)$ & 0.0372 & -1.5256 \\
\hline $\ln U$ & & & & & $-6.8130^{\star \star *}$ & $(\mathrm{C}, \mathrm{T}, 0)$ & 0.0000 & 0.0084 \\
\hline
\end{tabular}

Notes: 1$)^{* * *},{ }^{* *},{ }^{*}$ The assumption that the unit root is rejected at a significant level of $1 \%, 5 \%$ and $10 \%$, respectively. 2) (C,T,L) Represents constant terms, trend values, and lag levels, respectively.

\subsection{Least Square Regression Analysis}

A regression equation is established with DPR, DPPR, lnRGDP, lnRGDPP as dependent variables and with $\Delta \operatorname{lnRFPI}, \triangle \operatorname{lnRFDI}, \triangle \ln R F I A, \Delta \operatorname{lnRFPIP,} \Delta \operatorname{lnRFDIP}$, $\triangle \operatorname{lnRFIAP}$ and $\Delta \mathrm{luU}$ as independent variables, and the results are shown in Table 3. It can be seen from the table that none of the eight linear regression equations is significant. Among the independent variables, only $\mathrm{T}$ for the relative FDI index $\triangle \operatorname{lnRFDI}$ and $\triangle \operatorname{lnRFDIP}$ in regression equations which dependent variables are DPR and DPPR are significant, but the others are not significant. The indicators for the development of foreign capital insurance market such as $\triangle \operatorname{lnRFPI}, \Delta \operatorname{lnRFIA}, \Delta \operatorname{lnRFPIP}, \triangle \ln R F I A P$ and $\Delta \mathrm{luU}$ are not significant. It can be concluded that China's foreign direct investment (FDI) promotes China's economic growth, and the relationship between the development of foreign capital insurance market and China's economic growth is not significant.

\subsection{Granger Causality Test}

The Granger causalities between DPR, DPPR with $\triangle \operatorname{lnRFPI}, \triangle \operatorname{lnRFIA}, \triangle \operatorname{lnRFPIP}$, $\triangle \operatorname{lnRFIAP,} \Delta \ln \mathrm{U}$, and between $\ln R G D P, \ln R G D P P$ with $\triangle \ln R F P I P, \triangle \ln R F I A P$, $\Delta \mathrm{luU}$ are examined. The results are as shown in Table 4.

According to the test, Granger causality tests, refuse that DPR,DPPR are not the Granger reason of $\triangle \operatorname{lnRFIA}$, regarding DPR, DPPR as the Granger reason of $\triangle \operatorname{lnRFIA}$, that is, China's economic growth promotes the growth of the real assets of foreign capital insurance institutions; refuse that DPR, DPPR are not the Granger reason of $\triangle$ lnRFIAP, considering that DPR, DPPR are the Granger reason of $\triangle$ lnRFIAP, that is, China's economic growth promotes the increase of per capita real assets of foreign capital insurance institutions; reject that DPR, DPPR are not the Granger cause of $\Delta \ln U$, considering that DPR, DPPR are the Granger cause of $\Delta \ln U$, that is, China's economic growth has promoted the overall increase 
Table 3. General regression analysis on variables between the development of foreign capital insurance market and economic growth in China.

\begin{tabular}{|c|c|c|c|c|c|c|c|c|c|c|c|}
\hline $\begin{array}{l}\text { Dependent } \\
\text { variables }\end{array}$ & $\mathrm{C}$ & $\Delta \operatorname{lnRFPI}$ & $\Delta \ln R F D I$ & $\Delta \ln R F I A$ & $\Delta \ln R F P I P$ & $\Delta \operatorname{lnRFDIP}$ & $\Delta \ln R F I A P$ & $\Delta \ln U$ & $\mathrm{R}^{2}$ & $\mathrm{~F}$ & D-W \\
\hline \multirow{6}{*}{ DPR } & 0.0822 & 0.0152 & 0.0884 & 0.0112 & & & & 0.0057 & 0.2919 & 2.680 & 0.8581 \\
\hline & $(8.0711)$ & $(0.6896)$ & $(2.3894)$ & $(0.5725)$ & & & & $(0.1573)$ & & & \\
\hline & 0.0899 & & 0.0995 & & & & & & 0.2550 & 9.9257 & 0.8215 \\
\hline & $(12.2274)$ & & $(3.1505)$ & & & & & & & & \\
\hline & 0.0831 & & & & 0.0160 & 0.0908 & 0.0108 & 0.0046 & 0.3006 & 2.7936 & 0.8658 \\
\hline & $(8.3160)$ & & & & $(0.7283)$ & $(2.4549)$ & $(0.5554)$ & $(0.1274)$ & & & \\
\hline \multirow{6}{*}{ DPPR } & 0.0723 & 0.0140 & 0.0809 & 0.0136 & & & & 0.0084 & 0.2563 & 2.2399 & 0.7709 \\
\hline & $(6.7424)$ & $(0.6055)$ & $(2.0760)$ & $(0.6582)$ & & & & $(0.2192)$ & & & \\
\hline & 0.0806 & 0.0943 & & & & & & & 0.2169 & 8.0305 & 0.7260 \\
\hline & (10.4084) & $(2.8338)$ & & & & & & & & & \\
\hline & 0.0731 & & & & 0.0150 & 0.0836 & 0.0132 & 0.0072 & 0.2658 & 2.3256 & 0.7766 \\
\hline & $(6.9495)$ & & & & $(0.6483)$ & $(2.1469)$ & $(0.6424)$ & $(0.1873)$ & & & \\
\hline \multirow{2}{*}{ LnRGDP } & 10.3739 & & & & -0.2811 & -1.2168 & 0.2796 & 0.0530 & 0.0751 & 0.5280 & 0.1338 \\
\hline & $(42.2489)$ & & & & $(-0.5208)$ & $(-1.3396)$ & $(0.5843)$ & $(0.0594)$ & & & \\
\hline \multirow{2}{*}{ LnRGDPP } & 7.8638 & & & & -0.2600 & -1.0780 & 0.2303 & -0.0055 & 0.0739 & 0.5187 & 0.1303 \\
\hline & $(34.8964)$ & & & & $(-0.5251)$ & $(-1.2933)$ & $(0.5243)$ & $(-0.0068)$ & & & \\
\hline
\end{tabular}

Notes: the data in parentheses are $\mathrm{T}$ values.

Table 4. Grainger causality test on variables between foreign capital insurance market development and economic growth (continued on next page).

\begin{tabular}{|c|c|c|c|c|}
\hline Null hypothesis H0 & Lag order & Chi-Sq & $\mathrm{P}$ & conclusion \\
\hline$\triangle \operatorname{lnRFPI}$ is not the Granger cause of DPR & 1 & 0.1633 & 0.6862 & not refuse \\
\hline DPR is not the Granger cause of $\triangle \ln R F P I$ & 1 & 0.3196 & 0.5719 & not refuse \\
\hline$\triangle \operatorname{lnRFIA}$ is not the Granger cause of DPR & 4 & 0.4235 & 0.9805 & not refuse \\
\hline DPR is not the Granger cause of $\triangle \operatorname{lnRFIA}$ & 4 & 46.9305 & 0.0000 & refuse \\
\hline$\triangle \operatorname{lnRFPIP}$ is not the Granger cause of DPR & 1 & 0.1733 & 0.6772 & not refuse \\
\hline DPR is not the Granger cause of $\triangle \ln R F P I P$ & 1 & 0.3410 & 0.5593 & not refuse \\
\hline$\triangle \operatorname{lnRFIAP}$ is not the Granger cause of DPR & 4 & 0.4265 & 0.9802 & not refuse \\
\hline DPR is not the Granger cause of $\triangle \ln R F I A P$ & 4 & 46.7603 & 0.0000 & refuse \\
\hline$\Delta \mathrm{luU}$ is not the Granger cause of DPR & 3 & 1.3267 & 0.7228 & not refuse \\
\hline DPR is not the Granger cause of $\Delta l u U$ & 3 & 14.1252 & 0.0027 & refuse \\
\hline$\triangle \operatorname{lnRFPI}$ is not the Granger cause of DPPR & 1 & 0.1375 & 0.7108 & not refuse \\
\hline DPPR is not the Granger cause of $\Delta \ln R F P I$ & 1 & 0.2793 & 0.5856 & not refuse \\
\hline$\triangle \operatorname{lnRFIA}$ is not the Granger cause of DPPR & 4 & 0.4210 & 0.9807 & not refuse \\
\hline DPPR is not the Granger cause of $\triangle \ln R F I A$ & 4 & 46.4839 & 0.0000 & refuse \\
\hline$\Delta \operatorname{lnRFPIP}$ is not the Granger cause of DPPR & 1 & 0.1481 & 0.7003 & not refuse \\
\hline DPPR is not the Granger cause of $\triangle \operatorname{lnRFPIP}$ & 1 & 0.3232 & 0.5697 & not refuse \\
\hline
\end{tabular}


Continued

\begin{tabular}{|c|c|c|c|c|}
\hline$\Delta \ln R F I A P$ is not the Granger cause of DPPR & 4 & 0.4198 & 0.9808 & not refuse \\
\hline DPPR is not the Granger cause of $\triangle \ln R F I A P$ & 4 & 46.2010 & 0.0000 & refuse \\
\hline$\Delta \mathrm{luU}$ is not the Granger cause of DPPR & 3 & 1.2080 & 0.7511 & not refuse \\
\hline DPPR is not the Granger cause of $\Delta \mathrm{luU}$ & 3 & 14.4702 & 0.0023 & refuse \\
\hline$\Delta \ln R F P I P$ is not the Granger cause of $\ln R G D P$ & 2 & 0.6368 & 0.7273 & not refuse \\
\hline $\ln R G D P$ is not the Granger cause of $\Delta \ln R F P I P$ & 2 & 0.7869 & 0.6747 & not refuse \\
\hline$\Delta \operatorname{lnRFIAP}$ is not the Granger cause of $\ln R G D P$ & 5 & 1.5620 & 0.9058 & not refuse \\
\hline $\ln R G D P$ is not the Granger cause of $\triangle \ln R F I A P$ & 5 & 37.5735 & 0.0000 & refuse \\
\hline$\Delta \mathrm{luU}$ is not the Granger cause of lnRGDP & 2 & 0.4157 & 0.8123 & not refuse \\
\hline $\operatorname{lnRGDP}$ is not the Granger cause of $\Delta \mathrm{luU}$ & 2 & 2.6610 & 0.2643 & not refuse \\
\hline$\Delta \operatorname{lnRFPIP}$ is not the Granger cause of $\ln R G D P P$ & 2 & 0.6368 & 0.7273 & not refuse \\
\hline $\ln R G D P P$ is not the Granger cause of $\triangle \ln R F P I P$ & 2 & 0.7869 & 0.6747 & not refuse \\
\hline$\Delta \operatorname{lnRFIAP}$ is not the Granger cause of $\ln R G D P P$ & 5 & 1.5620 & 0.9058 & not refuse \\
\hline $\operatorname{lnRGDPP}$ is not the Granger cause of $\triangle \ln R F I A P$ & 5 & 37.5735 & 0.0000 & refuse \\
\hline$\Delta \mathrm{luU}$ is not the Granger cause of $\ln R G D P P$ & 2 & 0.4367 & 0.8039 & not refuse \\
\hline $\operatorname{lnRGDPP}$ is not the Granger cause of $\Delta$ luU & 2 & 3.0078 & 0.2223 & not refuse \\
\hline
\end{tabular}

in the number of foreign-funded insurance institutions; reject that lnRGDP, $\operatorname{lnRGDPP}$ are not the Granger reason of $\triangle$ lnRFIAP, believing that lnRGDP, lnRGDPP are the Granger cause of $\triangle \operatorname{lnRFIAP}$, that is, the real economic growth of China or China's per capita level promote the growth of real assets of foreign capital insurance institutions per capita.

\subsection{Conclusions and Interpretations}

The conclusions can be drawn from the above analysis: China's foreign direct investment has promoted China's economic growth, the development of foreign capital insurance market has not promoted China's economic growth, and China's economic growth has generally promoted the development of foreign capital insurance market. In the theoretical analysis, the channels of insurance market acting on economic growth are not smooth enough for foreign capital in China, and its action modes may be mainly applicable to China's domestic insurance market. The effect of FDI on China's economic growth may not be realized mainly through the foreign capital insurance market. The relationship between the development of China's foreign capital insurance market and economic growth is demand-driven. In addition, our hypothesis formula (2) is only valid for FDI, not for FPI FIA, (5) only for FDI/N, and not for FPI/N, FIA/N.

For a long time, China's regulatory authorities adopt different policies towards Chinese and foreign insurance institutions. The regulatory policy on domestic insurance companies was relatively loose, and the supervision of foreign-funded insurance companies was relatively strict. The approval speed of thousands of branches of Chinese insurance companies is relatively fast, and it is 
difficult to apply for foreign investment even if it is a branch. In addition, there are restrictions on the types of business of foreign capital insurance companies. China has not fully opened up the foreign capital insurance market. Foreign capital entering China's insurance market was mostly in the form of joint ventures, and its shareholding ratio was limited to a certain extent. There is a phenomenon of foreign investment entering the Chinese insurance market, which shows that they cannot fit the environment in china at first. In order to adapt to China's insurance market, it is generally necessary to develop in the order of agency offices, Chinese-foreign joint venture insurance companies, and wholly owned insurance companies. Because Chinese nationals did not have enough knowledge of foreign-funded insurance companies and not many of their insurance products were used directly, most of these foreign-funded insurance companies relied on their own country's enterprises and employees in China, domestic agencies and personnel in China, and some other foreign institutions and personnel in China who had contacts and knowledge of their global groups. Many local insurance companies in China have government background or are controlled by the government. In terms of policy and emotion, they have had a lot of care for these insurance companies. What is more important is that the Chinese people are more familiar with these insurance companies and have been used to buying the products of these companies, but some of the products of foreign insurance companies having been had a relatively high threshold, which is difficult for the Chinese to accept. The Asian financial crisis and the sub-prime mortgage crisis in the United States also have had a certain squeezing effect on the development of foreign capital financial markets.

However, China's economic growth has put forward demand for various types of insurance products. While some Chinese insurance companies do not have a dominant business, foreign insurance companies can make great efforts to provide them. When there are vacancies in China's domestic insurance market or when services cannot keep up, foreign insurance companies can make up for it. In addition, with the deepening and promotion of China's reform and opening up, China's policy of opening up to foreign capital insurance companies is gradually looser, which provides a corresponding space for the development of foreign capital insurance market.

\section{Policy Suggestions}

The Chinese Government continues to implement the policy of reform and opening to the outside world and further expands the scope and depth of opening up. The Chinese government should not be suspicious or hesitant about the reform and opening up to the outside world and worry about the further impact on the state-owned economy. Instead, it should deepen the reform relative to international economy and expand the opening up of some monopoly industries and departments. It should introduce stock system and foreign capital, introduce market mechanism. Still, Chinese government should increase its efforts to at- 
tract foreign direct investment, make full use of foreign capital and improve its efficiency. It should pay attention to the rational distribution of foreign direct investment in various industries and regions, especially in the industries and the products which is in the shortage of in China, so as to form a situation in which all sectors and fields of China go hand in hand.

In the meanwhile, Chinese government should increase the opening of foreign capital insurance market and gradually achieve equal treatment for Chinese and foreign insurance companies, relax restrictions on the establishment, business development and industry supervision of foreign-funded insurance companies, gradually give national treatment, reduce the unfair competition in the market, and open up the channels through which the foreign-funded insurance market acts on economic growth, and fully play the role that the foreign capital insurance market should play to China's economic growth. At last, in the process of opening up the insurance market, China needs to control financial risks and maintain financial stability. Opening up the financial market will inevitably bring about financial risks, and international financial risks will inevitably spread to China. In order to maintain China's financial stability and ensure the healthy development and high efficiency of China's insurance market, the government must take a set of measures to prevent and control financial risks, prevent the sharp fluctuations of the insurance market, and strengthen international regulatory cooperation.

\section{Conflicts of Interest}

The authors declare no conflicts of interest regarding the publication of this paper.

\section{References}

[1] Han, L., Li, D., Moshirian, F. and Tian, Y. (2010) Insurance Development and Economic Growth. Geneva Papers on Risk and Insurance: Issues and Practice, 35, 183-199. https://doi.org/10.1057/gpp.2010.4

[2] Chen, P.-F., Lee, C.-C. and Lee, C.-F. (2012) How Does the Development of the Life Insurance Market Affect Economic Growth? Some International Evidence. Journal of International Development, 24, 865-893. https://doi.org/10.1002/jid.1765

[3] Gyu, C.S. (2006) A Causality Analysis of Regional Economic Growth and Financial Role of Life Insurance in Korea. Journal of Industrial Economics and Business, 1, 49-72.

[4] Malloy, L.C., Pearson-Merkowitz, S. and Morris, I.L. (2016) State-Sponsored Health Insurance and State Economic and Employment Growth. Politics \& Policy, 44, 945-975. https://doi.org/10.1111/polp.12176

[5] Ul Din, S.M., Abu-Bakar, A. and Regupathi, A. (2017) Does Insurance Promote Economic Growth: A Comparative Study of Developed and Emerging/Developing Economies? Cogent Economics \& Finance, 5, 1-12. https://doi.org/10.1080/23322039.2017.1390029

[6] Zhou, C., Wu, C., Li, D. and Chen, Z. (2012) Insurance Stock Returns and Economic Growth. Geneva Papers on Risk and Insurance: Issues and Practice, 37, 405-428. 
https://doi.org/10.1057/gpp.2012.22

[7] Concha, Á. and Taborda, R. (2014) Insurance Use and Economic Growth in Latin America. Some Panel Data Evidence partir des données de panel partir de datos de panel. Lecturas de Economía, 81, 31-45.

[8] Nam, S. (2013) The Long-Run Relationship between Insurance Development and Economic Growth in China. The Journal of Asian Studies, 1, 105-130.

[9] Nam, S. (2006) A Study on the Causality between the Insurance Industry and Economic Growth. Korean Journal of Insurance, 74, 169-198.

[10] Kaushal, S. and Ghosh, A. (2017) Economic Growth and the Development of Banking and Insurance Sector in the Post-Liberalized India an Empirical Analysis. International Journal of Social Economics, 44, 2187-2207. https://doi.org/10.1108/IJSE-04-2016-0121

[11] Su, C.-W., Chang, H.-L. and Pan, G. (2013) Tests for Causality between Insurance Development and Economic Growth Using Asymptotic and Panel Bootstrap Distributions. Economic Computation and Economic Cybernetics Studies and Research, 47, 111-131.

[12] Pradhan, R.P., Dash, S., Pratap Maradana, R., Jayakumar, M. and Gaurav, K. (2017) Insurance Market Density and Economic Growth in Eurozone Countries: the Granger Causality Approach. Financial Innovation, 3, 17.

https://doi.org/10.1186/s40854-017-0065-x

[13] Olayungbo, D.O. (2015) Insurance and Economic Growth Nexus in Nigeria: Asymmetric Non-Linear Relationship under Heterogeneous Agents. African Development Review, 27, 248-261. https://doi.org/10.1111/1467-8268.12144

[14] Olayungbo, D.O. and Akinlo, A.E. (2016) Insurance Penetration and Economic Growth in Africa: Dynamic Effects Analysis using Bayesian TVP-VAR Approach. Cogent Economics \& Finance, 4, 1-19. https://doi.org/10.1080/23322039.2016.1150390

[15] Ward, D. and Zurbruegg, R. (2000) Does Insurance Promote Economic Growth? Evidence from OECD Countries. Journal of Risk and Insurance, 67, 489-506. https://doi.org/10.2307/253847

[16] Hu, H., Meng, S.U. and Lee, W. (2013) Insurance Activity and Economic Growth Nexus in 31 Regions of China: Bootstrap Panel Causality Test. Romanian Journal of Economic Forecasting, 16, 182-198.

[17] Lu, C. and Yanagihara, M. (2013) Life Insurance, Human Capital Accumulation and Economic Growth. Australian Economic Papers, 52, 52-60. https://doi.org/10.1111/1467-8454.12007

[18] Ul Din, S.M., Regupathi, A. and Regupathi, A. (2017) Insurance Effect on Economic Growth-Among Economies in Various Phases of Development. Review of International Business and Strategy, 27, 501-519. https://doi.org/10.1108/RIBS-02-2017-0010

[19] Alhassan, A.L. and Biekpe, N. (2016) Insurance Market Development and Economic Growth Exploring Causality in 8 Selected African Countries. International Journal of Social Economics, 43, 321-339. https://doi.org/10.1108/IJSE-09-2014-0182

[20] Sop, H.B. (2013) Does Insurance Market Activity Promote Economic Growth? Evidence from China. The Journal of Modern China Studies, 45, 241-266. 